\title{
Semiflexible Immunobrushes Induce Enhanced T Cell Activation and Expansion
}

\author{
Roel Hammink,* Jorieke Weiden, Dion Voerman, Carlijn Popelier, Loek J. Eggermont, \\ Marjolein Schluck, Carl G. Figdor, and Martijn Verdoes*
}

Cite This: ACS Appl. Mater. Interfaces 2021, 13, 16007-16018

Read Online

ACCESS |

山ll Metrics \& More

四 Article Recommendations

S1 Supporting Information

ABSTRACT: A variety of bioactive materials developed to expand $\mathrm{T}$ cells for adoptive transfer into cancer patients are currently evaluated in the clinic. In most cases, $\mathrm{T}$ cell activating biomolecules are attached to rigid surfaces or matrices and form a static interface between materials and the signaling receptors on the $\mathrm{T}$ cells. We hypothesized that a $\mathrm{T}$ cell activating polymer brush interface might better mimic the cell surface of a natural antigen-presenting cell, facilitating receptor movement and concomitant advantageous mechanical forces to provide enhanced $\mathrm{T}$ cell activating capacities. Here, as a proof of concept, we synthesized semiflexible polyisocyanopeptide (PIC) polymerbased immunobrushes equipped with $\mathrm{T}$ cell activating agonistic anti-CD3 $(\alpha \mathrm{CD} 3)$ and $\alpha \mathrm{CD} 28$ antibodies placed on magnetic microbeads. We demonstrated enhanced efficiency of ex vivo expansion of activated primary human $\mathrm{T}$ cells even at very low numbers of stimulating antibodies compared to rigid beads. Importantly, the immunobrush architecture appeared crucial for this improved $\mathrm{T}$ cell activating capacity. Immunobrushes outperform current benchmarks by producing higher numbers of $\mathrm{T}$ cells exhibiting a combination of beneficial phenotypic characteristics, such as reduced exhaustion marker expression, high cytokine production, and robust expression of cytotoxic hallmarks. This study indicates that semiflexible immunobrushes have great potential in making $\mathrm{T}$ cell-based immunotherapies more effective.

KEYWORDS: artificial antigen-presenting cell, polymer brush surface, adoptive cell therapy, polyisocyanopeptide, immunotherapy

\section{INTRODUCTION}

The human immune system has the capability to identify and clear infected or malignant cells, ${ }^{1}$ but in the case of cancer, the immune system often fails. ${ }^{2,3}$ Immunotherapies have therefore emerged to boost the immune system to better fight malignancies. As $\mathrm{T}$ cells play a central role in the clearance of cancer cells, many immunotherapies aim to increase tumorspecific $\mathrm{T}$ cell responses. ${ }^{4,5}$ For example, adoptive $\mathrm{T}$ cell therapy is aimed at strengthening the immune response by infusing autologous tumor-reactive $\mathrm{T}$ cells into cancer patients, thereby benefitting from their cytotoxic potential. ${ }^{6-10}$ To generate sufficient numbers of functional $\mathrm{T}$ cells, autologous $\mathrm{T}$ cells need to be activated and expanded ex vivo.

Current strategies for ex vivo $\mathrm{T}$ cell activation often make use of artificial antigen-presenting cells (aAPCs) that mimic the natural activation signals presented by antigen-presenting cells (APC) such as dendritic cells. ${ }^{11}$ For $\mathrm{T}$ cell activation, three main signals are important: (1) $\mathrm{T}$ cell receptor (TCR) stimulation; $^{12}$ (2) co-stimulation, for example, by engagement of the co-stimulatory receptor CD28 on T cells; ${ }^{13,14}$ and (3) the secretion and binding of cytokines. ${ }^{15} \mathrm{~A}$ common design for aAPCs is the use of rigid synthetic scaffolds that present signals 1 and 2, often using agonistic anti-CD3 ( $\alpha$ CD3) and $\alpha \mathrm{CD} 28$ antibodies, respectively. ${ }^{11,16,17}$ Protocols using these aAPCs for
T cell expansion are often complemented with soluble IL-2 as signal 3. Such rigid aAPCs have been developed in many shapes and sizes. ${ }^{11,18,19}$ Current standards for in vitro $\mathrm{T}$ cell activation are magnetic microbeads containing $\alpha \mathrm{CD} 3$ and $\alpha \mathrm{CD} 28$, most commonly Dynabeads with a diameter of 4.5 $\mu \mathrm{m}^{20-22}$

Adoptive cell therapies (ACTs) exploiting Dynabeads or similar rigid aAPCs for $\mathrm{T}$ cell expansion have shown promising results in phase 1 and 2 clinical trials for hematological cancers and some solid cancers such as melanoma. 6,7,23,24 However, the practical feasibility of ACT and treatment efficacy are still hampered by the extensive ex vivo expansion that is needed to obtain enough cells for reinfusion. ${ }^{25-28}$ This expansion is not only a time-consuming and expensive process that limits the widespread application of ACT, but can also yield T cells with poor persistence and limited functionality in vivo. ${ }^{26,28-31}$ These limitations could be a consequence of the fact that rigid

Received: December 14, 2020

Accepted: March 24, 2021

Published: April 2, 2021 
spherical beads are poor mimics of natural APCs. APC membrane fluidity and receptor rearrangements play an important role during interaction with $\mathrm{T}$ cells and subsequent activation. $^{32}$ A wide range of new strategies are being developed to improve ex vivo $\mathrm{T}$ cell expansion. ${ }^{33-36}$ To further boost adoptive cell therapies, it is crucial to develop better aAPCs that activate and expand T cells ex vivo at higher rates, while generating $\mathrm{T}$ cells with optimal phenotypes and high functionality. Therefore, it is crucial to increase our understanding of how aAPC design impacts $\mathrm{T}$ cell activation to improve the development of novel aAPC strategies.

Recently, we introduced a new type of aAPC based on soluble semiflexible polyisocyanopeptide (PIC) polymers with a length of around $400 \mathrm{~nm}$. This scaffold is able to induce very potent and long-lasting $\mathrm{T}$ cell activation. ${ }^{37-40}$ The success of these aAPCs is attributed to the semiflexibility of the polymers, which is hypothesized to enable high motility of the signals that are attached. At the same time, the polymer backbone is stiff enough to present the signals in a stretched confirmation. The $\mathrm{T}$ cell activating capacity of PIC-based aAPCs is remarkable, especially given the fact that their size is far below the optimal $4-5 \mu \mathrm{m}$ size range frequently used for aAPCs, ${ }^{18}$ which is advantageous, for example, for in vivo applications. In this work, we aim to combine the best of two worlds by grafting $\mathrm{T}$ cell activating PICs onto optimally sized magnetic microbeads, allowing easy separation from the expanded T cells. We hypothesize that due to their semiflexible nature, the grafted PICs will form a brush surface to more effectively present the activating signals, which will result in improved $\mathrm{T}$ cell expansion performance compared to rigid beads.

Here, we show the design and functionalization of PICgrafted magnetic microbeads with $\alpha \mathrm{CD} 3$ and $\alpha \mathrm{CD} 28$ agonistic antibodies. We illustrate that the brush configuration of the polymer is crucial for efficient $\mathrm{T}$ cell activation and we optimized the $\mathrm{T}$ cell stimulating potential over a range of design parameters, such as antibody ratio and density. In addition, we demonstrate that these immunobrushes outperform rigid beads to which the same signals are directly attached to the surface. Finally, we show that the $\alpha \mathrm{CD} 3 / \alpha \mathrm{CD} 28$ PIC immunobrush outperformed clinically approved expansion systems like CD3/CD28 Dynabeads or T Cell TransAct in expansion of primary $\mathrm{T}$ cells with beneficial phenotypic characteristics using standard operation procedures similar to those used for clinical application.

\section{EXPERIMENTAL SECTION}

2.1. Synthesis of Biotin End-Functional PIC. End-functional PIC were synthesized according to the previously reported protocol. ${ }^{41}$ Briefly, PICs with an allyl containing first block were prepared. For this, methoxy-, allyl-, and azide-terminated monomers were prepared as described according to the literature. ${ }^{37,41}$ For the polymerization of the first block, methoxy-terminated monomer and allyl-terminated monomer were dissolved in a 1:1 molar ratio in dry toluene obtained from an MBraun SPS 800 solvent system at a total monomer concentration of $27.7 \mathrm{mM}$. To this mixture, a $4 \mathrm{mM}$ catalyst solution was added $\left(\mathrm{Ni}\left(\mathrm{ClO}_{4}\right)_{2} \cdot 6 \mathrm{H}_{2} \mathrm{O}\right.$ in 9:1 toluene/ethanol) with a monomer/catalyst ratio of 100:1 and was reacted for $10 \mathrm{~min}$. Next, for the second block, a solution of azide monomer $(0.66 \mathrm{mg}, 0.0018$ $\mathrm{mmol}$ ) and methoxy monomer (19.34 $\mathrm{mg}, 0.054 \mathrm{mmol})$ in dry toluene $(0.50 \mathrm{~mL})$ was added and the polymerization was stirred overnight at room temperature (RT). Isocyanide consumption was confirmed by disappearance of the characteristic IR absorbance at $2140 \mathrm{~cm}^{-1}$. The polymers were precipitated three times in diisopropyl ether and air-dried overnight to give an off-white solid $(15.35 \mathrm{mg}$, 77\%). The helical backbone of the PIC was confirmed by circular dichroism spectroscopy of PIC solutions in phosphate-buffered saline (PBS) $\mathrm{pH} \mathrm{7.4.}{ }^{43}$ The average polymer length was determined by atomic force spectroscopy (AFM, Figure S1) using a Nanoscope IV instrument (Bruker) and NSG-10 tapping mode tips (NT-MDT) and found to be $205 \mathrm{~nm} .{ }^{37}$ The allyl functionalities in the first block were then converted to biotin via the nitrile imine-mediated tetrazole-ene cycloaddition (NITEC) reaction using a tetrazole-biotin compound as described before. ${ }^{41}$ Biotin conjugation was confirmed by measuring the fluorescence of the pyrazolines that are formed upon conjugation using a SPARK M10 plate reader from TECAN. The biotin endfunctional PIC was then dissolved at $2 \mathrm{mg} / \mathrm{mL}$ in PBS and labeled overnight at $4{ }^{\circ} \mathrm{C}$ with dibenzocyclooctyne (DBCO)-conjugated Alexa Fluor 594 dye (Click Chemistry Tools) using a 1:500 ratio of dye/azide and used without purification.

2.2. Functionalization of Antibodies. Anti-human CD3 antibodies (clone OKT3, BioXcell) and anti-human CD28 antibodies (clone 9.3, BioXcell) were functionalized with dibenzocyclooctyne (DBCO) or biotin and fluorescent dyes as described previously. ${ }^{39,43}$ To ensure that the DBCO-functionalized antibodies contain the same amount of dyes as their biotin-functionalized counterparts, the antibodies were first conjugated with the dyes. The antibody storage buffer was converted to $50 \mathrm{mM}$ borate buffer $\mathrm{pH} 8.5$ using Amicon centrifugal filters ( $30 \mathrm{kDa}$ cutoff, Merck), and the antibodies were reacted with 2.5 equiv of Atto 488-NHS ester (A488, Atto-TEC $\mathrm{GmbH}$, for $\alpha \mathrm{CD} 3$ ) and Alexa Fluor 647-NHS ester (AF647, Thermo Fischer Scientific, for $\alpha \mathrm{CD} 28)$ for $2 \mathrm{~h}$ at $4{ }^{\circ} \mathrm{C}$. Dye-functionalized proteins were purified using a $5 \mathrm{~mL} 40 \mathrm{~K}$ Zeba spin desalting column (Thermo Fischer Scientific). The batches of dye-functionalized antibodies were then redissolved in $50 \mathrm{mM}$ borate buffer $\mathrm{pH} 8.5$; half were reacted with 5 equiv DBCO-PEG4-NHS (Jena Bioscience) and the other half with 5 equiv NHS-PEG4-biotin (Jena Bioscience) for $2 \mathrm{~h}$ at $4{ }^{\circ} \mathrm{C}$. The functionalized proteins were again purified using a $5 \mathrm{~mL} 40 \mathrm{~K}$ Zeba spin desalting column. The degree of labeling (DOL) of DBCO and fluorescent dyes was determined using a NanoDrop 2000c spectrophotometer. The concentrations of protein, DBCO, and dye were calculated based on the absorbance at 280, 309, 501 , and $650 \mathrm{~nm}$ and corrected for overlap in the absorbance spectra of the individual molecules. Typically, the DOL of DBCO was 2-4 and the DOL of the dyes was $1-3$.

2.3. Conjugation of DBCO-Conjugated Antibodies to PIC. A $1 \mathrm{mg} / \mathrm{mL}$ solution of the biotin end-functional PIC in PBS $(50 \mu \mathrm{L}$, $0.05 \mathrm{mg}, 4.4 \mathrm{nmol}$ azide monomer) was added to a solution of DBCO- and AF647-labeled $\alpha \mathrm{CD} 28$ and DBCO- and A488-labeled $\alpha \mathrm{CD} 3$ in PBS $(450 \mu \mathrm{L})$ in the desired antibody ratios. The mixture was reacted overnight at RT. To prevent PIC cross-linking in the following steps, excess unreacted DBCO conjugated to the antibodies was quenched by addition of 1000 equiv azido propylamine from a $100 \mu \mathrm{M}$ stock solution in dimethyl sulfoxide (DMSO) and was reacted for $2 \mathrm{~h}$ at room temperature. The conjugated polymer, when used for grafting, was then used without further purification as unreacted antibodies are removed by washing the beads after grafting. When used as soluble antibody-functionalized PIC for activation or for determination of antibody per PIC, they were purified using affinity purification according to the literature. ${ }^{43}$ The amount of antibody per PIC of purified polymer was determined by measuring the fluorescence of the respective labels on PIC, $\alpha \mathrm{CD} 3$, and $\alpha \mathrm{CD} 28$ and comparing it to trendlines of the pure labeled compounds.

2.4. Synthesis of PIC Beads and Ab Beads. Streptavidin-coated magnetic beads were prepared from $4.5 \mu \mathrm{m}$ beads with a tosylactivated surface (Dynabeads M450 Tosyl from Thermo Fischer Scientific). Tosyl bead suspension $(1 \mathrm{~mL})$ was washed three times with $50 \mathrm{mM}$ borate buffer $\mathrm{pH} 8.5$ using a magnetic separation rack from Westburg BV. The beads were resuspended in $1 \mathrm{~mL}$ of $20 \mathrm{mM}$ streptavidin in borate buffer $\mathrm{pH} 8.5$ and reacted overnight at room temperature. Next, the beads were washed $2 \times$ with $0.05 \%$ PBS Tween and $3 \times$ with PBS and resuspended in $1 \mathrm{~mL}$ of PBS. For the preparation of PIC beads or Ab beads, the supernatant was first removed using the magnet and then replaced with a solution of the 
desired biotin end-functional PIC or biotin-functionalized antibodies. The beads were incubated with the desired biotin compounds on a rotator overnight at $4{ }^{\circ} \mathrm{C}$ and washed with $2 \times 0.05 \%$ PBS Tween and $3 \times$ with PBS. The beads were analyzed by flow cytometry on a BD FACS Verse cytometer and via the previously reported stripping assay, ${ }^{41}$ with the exception that as a stripping solution, $3 \mathrm{mM}$ biotin in $2 \%$ sodium dodecyl sulfate (SDS) in Milli-Q water was used. For the beads made for the antibody density series, only flow cytometry analysis was performed to determine antibody densities and PIC densities from the $\mathrm{Ab} / \mathrm{PIC}$ ratio determined after polymer purification

For the preparation of flat PIC beads, a similar protocol was followed, but a PIC with random bound biotins instead of the endfunctional PIC was used. To attach the biotin in a random manner, half of the azides in the PIC were converted to biotin, using DBCOPEG4-biotin. This flexible poly(ethylene glycol) (PEG) spacer, combined with the semiflexibility of the PIC backbone and the flexible linkers connecting the antibodies to the PIC, should provide ample flexibility and accessibility of the antibodies to the $\mathrm{T}$ cells. The remaining azides were used for the conjugation of the antibodies. The cross-linked PIC beads were prepared by omitting the quenching of excess DBCO on the antibodies, after which the exact same protocol for PIC bead preparation was followed as above. For the flow cytometry analysis, single beads were gated using a plot of forward scatter versus side scatter, and mean fluorescence intensities (MFIs) of the A488 and AF647 labels were recorded using fluorescein isothiocyanate (FITC) and APC channel, respectively. The beads were stored as a suspension in PBS $(1 \mathrm{mg} / \mathrm{mL})$ and used within 2 weeks of preparation. Before using them to activate $\mathrm{T}$ cells, they were freshly washed three times with sterile PBS and then resuspended in sterile X-Vivo medium with $2 \%$ human serum at a concentration of 4 $\times 10^{7}$ beads $/ \mathrm{mL}$ and used directly in $\mathrm{T}$ cell activation assays.

2.5. Isolation of Primary Human Pan T Cells and Activation. Fresh peripheral blood mononuclear cells (PBMCs) were obtained by Ficoll density centrifugation of buffy coats obtained from healthy donors in accordance with recommendations of institutional guidelines. All subjects gave written informed consent in accordance with the Declaration of Helsinki. Pan T cells were isolated from peripheral blood leukocytes using the Pan T cell isolation kit (Miltenyi Biotec). $\mathrm{T}$ cell purity was determined by flow cytometry staining with $\mathrm{CD} 3$ (eBioscience) and was typically $>98 \%$. For the conditions where the proliferation after 3 days was measured, isolated $\mathrm{T}$ cells were stained with CellTrace Violet before activation. This staining was performed by incubating the cell suspension in $2.5 \mu \mathrm{M}$ CellTrace Violet solution in PBS at room temperature for $10 \mathrm{~min}$ in the dark. The reaction was then quenched by adding an equal volume of fetal bovine serum, and cells were washed three times with X-Vivo medium containing $2 \%$ human serum.

The isolated $\mathrm{T}$ cells were cultured in 96-well u-bottom plates (Corning) using $10^{5}$ cells per well in a final volume of $200 \mu \mathrm{L}$ X-Vivo medium with $2 \%$ human serum. For the initial validation of the PIC beads, no IL-2 was added to the medium. For the expansion protocol, the medium was supplemented with $30 \mathrm{IU} / \mathrm{mL} \mathrm{IL}-2$ (Cell Genix). To stimulate cells, PIC beads were added ( 1 bead per cell, washed $3 \times$ in PBS): CD3/CD28 Dynabeads (Thermo Fischer Scientific) (1 bead per cell, washed $1 \times$ in PBS) or T Cell TransAct (Miltenyi Biotec) $(1: 100)$. The cells were incubated at $37{ }^{\circ} \mathrm{C}$ for a desired time. After 3 , 6,9 , and 11 days of culture, the medium was taken off. T cells were split in half, and $200 \mu \mathrm{L}$ of fresh medium with $30 \mathrm{IU} / \mathrm{mL} \mathrm{IL}-2$ was added.

2.6. IL-2 and IFN $\gamma$ Analysis by Enzyme-Linked Immunosorbent Assay (ELISA). After $20-24 \mathrm{~h}$ of cell culture, $125 \mu \mathrm{L}$ of supernatant was taken from each condition and stored at $-20^{\circ} \mathrm{C}$ until used. Cytokine production was quantified using standard sandwich ELISA kits for human IFN $\gamma$ (Invitrogen) and IL-2 (eBioscience) according to manufacturer's protocol.

2.7. Determining T Cell Activation and Proliferation. On day $1, \mathrm{~T}$ cells were transferred to v-bottom 96-well plates (Corning) and stained with the Zombie Violet Fixable Viability Kit (Biolegend). To determine $\mathrm{T}$ cell activation, we performed cell surface staining with CD8-BV510, CD4-APC-Cy7, CD69-PE, and CD25-PE-Cy7 (all BD
Biosciences). On day 3, we determined $\mathrm{T}$ cell proliferation by transferring $\mathrm{T}$ cells to v-bottom 96-well plates and staining with Fixable Viability Dye eFluor 780 (BD) followed by cell surface staining with CD4-PE (BD Biosciences) and CD8-BV510. All samples were acquired on the FACS Verse (BD Biosciences). The mean cell cycle of all $\mathrm{T}$ cells was determined as a measure for the average number of cell proliferation cycles. The mean cycle was calculated with the formula $\log 2(f)$, where $f$ is the CellTrace Violet mean fluorescence intensity (MFI) of all nonproliferated $\mathrm{T}$ cells divided by the CellTrace Violet MFI of all $\mathrm{T}$ cells.

2.8. T Cell Expansion and CD4/CD8 Ratio. To quantify expansion of the $\mathrm{T}$ cells over time, we transferred $\mathrm{T}$ cells on days 1,7 , and 14 to 96-well v-bottom plates and performed a cell surface staining with CD8-BV510 and CD4-APC Cy7. The cells were acquired and the cell number was quantified on an MACS Quant flow cytometer (Miltenyi Biotec) together with a propidium iodide staining (Miltenyi Biotec) to assess cell viability. The cell number was corrected for the number of times the cells were split during cell culture, and the fold expansion was calculated relative to the number of $\mathrm{T}$ cells put in the wells on day 0 (50.000).

2.9. T Cell Phenotype. On day 14, we transferred the cells to a 96-well v-bottom plate and performed flow cytometry stainings to assess the phenotype of the T cells. All of the cells were stained with Fixable Viability Dye eFluor 780, followed by staining according to the following panels:

(1) Memory phenotype-Cell surface: CD8-PE-Cy7 (Biolegend), CD95-BV421 (Biolegend), CD45RA-BV510 (Biolegend), CCR7-PE (BD Biosciences).

(2) Exhaustion-Cell surface: CD4-BV421 (Biolegend), CD8PECy7, PD-1-BV510 (BD Biosciences), TIM-3-PerCP-eFluor 710 (eBioscience).

To measure cytokine production and cytotoxicity, $\mathrm{T}$ cells were first restimulated for $5.5 \mathrm{~h}$ with $20 \mathrm{ng} / \mathrm{mL}$ phorbol myristate acetate (PMA) (Calbiochem), $1 \mu \mathrm{g} / \mathrm{mL}$ ionomycin (Sigma-Aldrich), $10 \mu \mathrm{g} /$ $\mathrm{mL}$ Brefeldin A (BFA) (Sigma-Aldrich), and $2 \mu \mathrm{M}$ monensin (eBioscience). For the cytotoxicity panel, at the same time, cells were incubated with CD107a-PeCy5 (BD Biosciences) for 5.5 h. Next, T cells were transferred to a 96-well v-bottom plate and stained with Fixable Viability Dye eFluor 780, followed by staining according to the following panels:

(1) Cytokine production-Cell surface: CD8-BV510, intracellular: IFNy-BV421 (BD Biosciences), IL-2-PE (eBioscience) TNF $\alpha$ PerCP/Cy5.5 (eBioscience).

(2) Cytotoxicity-Cell surface: CD4-BV421, intracellular: Granzyme B-PE (Biolegend).

For intracellular stainings, cells were fixated and permeabilized using a Fixation/Permeabilization Solution Kit (BD Biosciences). All samples were acquired on the FACS Verse, and the gates were set using fluorescence minus one (FMO) controls.

2.10. Statistics. Data are expressed as mean \pm standard error of the mean (SEM).

Statistical analyses were performed in GraphPad Prism 8.0.2 software using the appropriate testing methods, as indicated in the figure legends. Normality was tested using the D'Agostino-Pearson omnibus normality test. Statistical significance was defined as a twosided significance level of $<0.05$ indicated as $* p \leq 0.05$, ** $p \leq 0.01$, and $* * * p \leq 0.001$. Flow cytometry data were analyzed using FlowJo software version X 10.0.7r2 (Tree Star).

\section{RESULTS}

3.1. PIC Immunobrushes Effectively Stimulate T Cells. To synthesize $\mathrm{T}$ cell activating PIC immunobrushes, we applied a methodology we recently developed to graft PIC polymers to various surfaces. ${ }^{41}$ Here, we aimed to synthesize PIC block copolymers containing orthogonal functional groups to introduce $\mathrm{T}$ cell activating signals on one side of the polymer and use the other side to attach the polymers to 4.5 

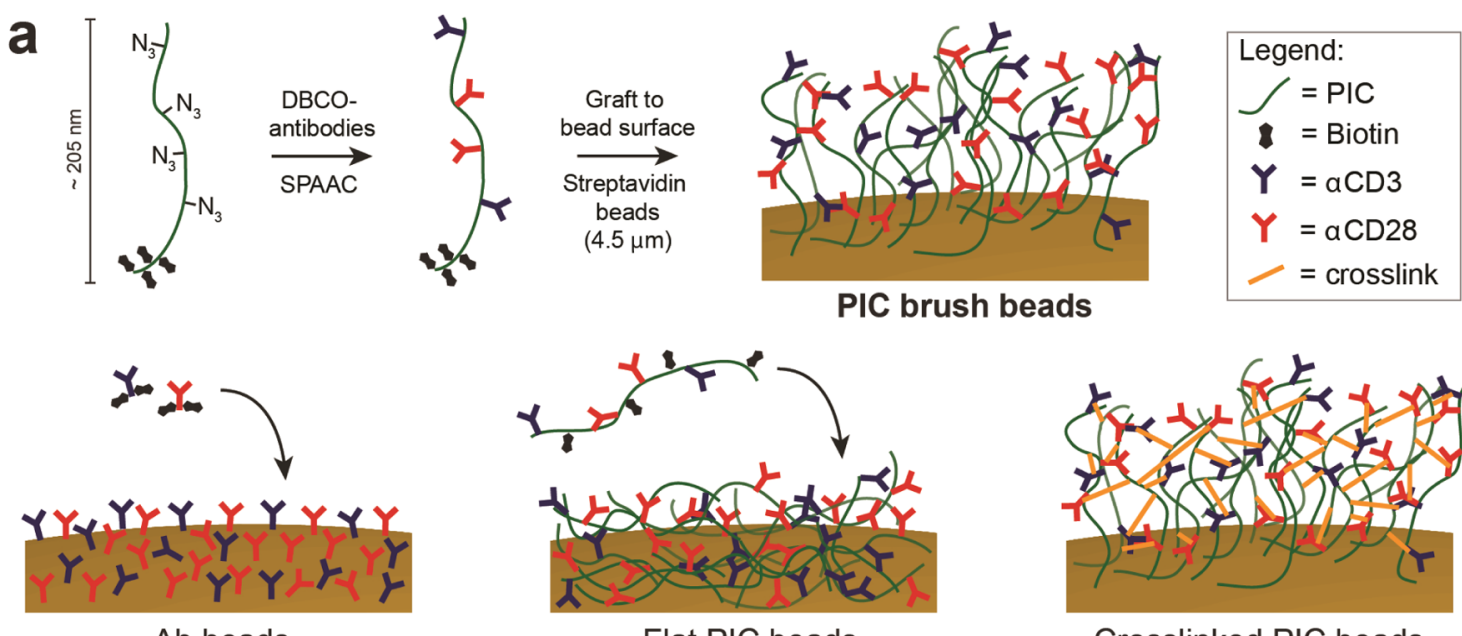

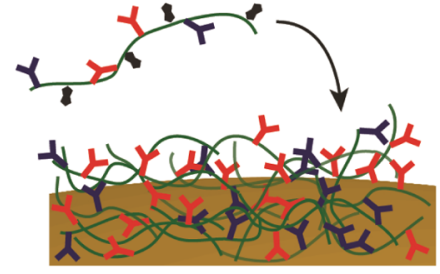

Flat PIC beads

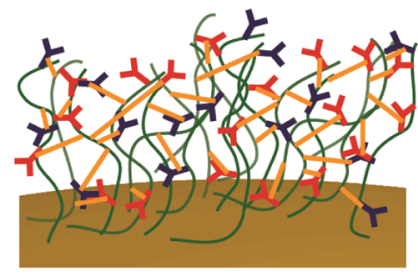

Crosslinked PIC beads
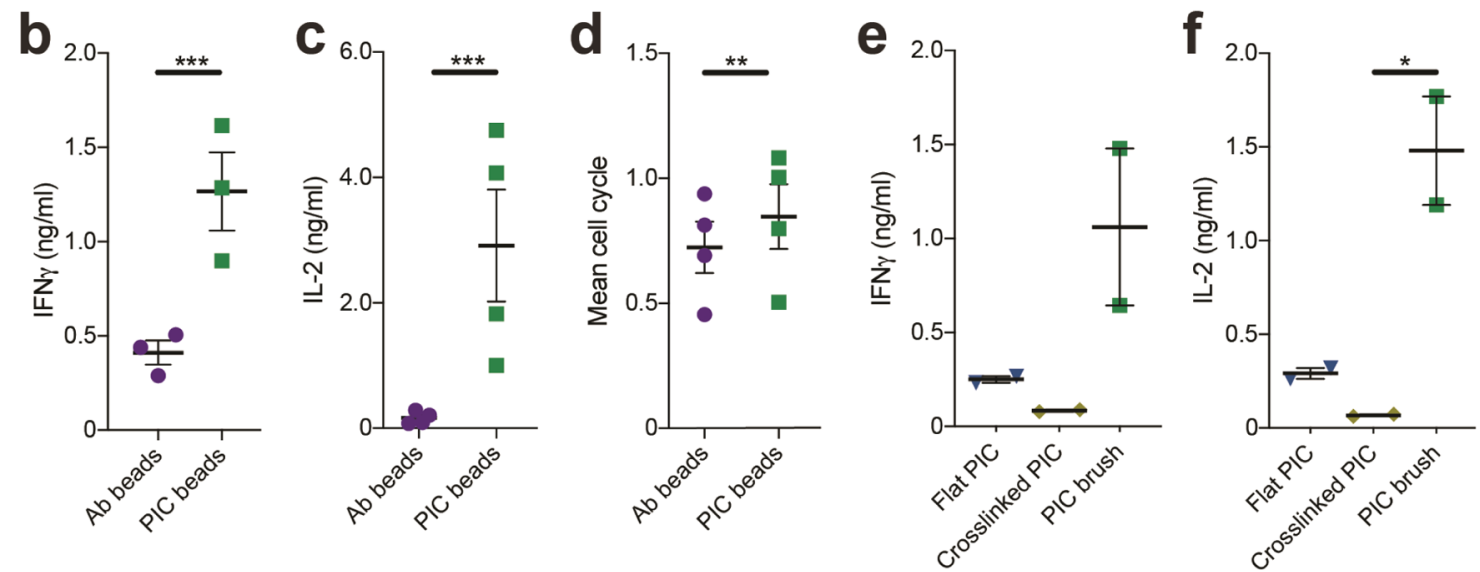

Figure 1. Synthesis and characterization of PIC immunobrush beads. (a) Schematic overview of the preparation of PIC brush beads (top), Ab beads (bottom left), flat PIC beads (bottom center), and cross-linked PIC beads (bottom right). (b, c) Production of IFN $\gamma$ (b, $n=3$ in two independent experiments) and IL-2 (c, $n=4$ in two independent experiments) after 20-24 h of human T cells stimulated with directly coupled antibody beads or PIC beads. (d) Mean cell cycle of proliferated human T cells on day 3, stimulated directly coupled antibody beads or PIC beads $n=4$ in two independent experiments. (b-d) A paired $t$ test was performed on log2-transformed data. (e, f) IFN $\gamma$ and IL-2 production of human T cells after 20-24 h stimulated with PIC beads with reduced mobility, $n=2$ in one independent experiment. An RM one-way analysis of variance (ANOVA) was performed on log2-transformed data with Geisser-Greenhouse correction, followed by Dunnett's multiple comparison test.

$\mu \mathrm{m}$ magnetic beads (Figure 1a). The first block contained allyl functional groups, which were subsequently modified with tetrazole-biotin via photoinduced nitrile imine-mediated tetrazole-ene cycloaddition (NITEC) reaction. The second, larger block contains azide functional groups, which can be used to "click" dibenzocyclooctyne (DBCO)-modified antibodies via a strain-promoted azide alkyne cycloaddition reaction (SPAAC) (Figure 1a). ${ }^{42}$ The ratio between the average length of the biotin and azide functional blocks was 1:20, with an average total length of $205 \mathrm{~nm}$ as determined with atomic force microscopy (Figure S1). Next, DBCOmodified $\alpha \mathrm{CD} 3$ and $\alpha \mathrm{CD} 28$ antibodies were "clicked" to the PIC block copolymers in different ratios (Table S1 for all formulations) to establish the optimal ratio for $\mathrm{T}$ cell activation and expansion. Subsequently, these antibody-functionalized polymers were grafted onto streptavidin-coated $4.5-\mu \mathrm{m}$-sized magnetic beads, to obtain the $\alpha \mathrm{CD} 3 / \alpha \mathrm{CD} 28$ PIC brush beads to be characterized for their $\mathrm{T}$ cell activating capacities (Figure 1a).

Having synthesized the $\alpha \mathrm{CD} 3 / \alpha \mathrm{CD} 28$ PIC immunobrush beads, we set out to analyze their ability to stimulate primary human $\mathrm{T}$ cells $\left(\mathrm{CD}^{+}\right.$and $\mathrm{CD} 8^{+}$Pan $\mathrm{T}$ cells $)$. The performance of the PIC immunobrush beads was compared to that of beads with similar quantities and ratios of $\alpha \mathrm{CD} 3$ and $\alpha \mathrm{CD} 28$ antibodies directly attached to the particle surface $(\mathrm{Ab}$ beads, Figure 1a) (PIC beads: 4.2 ratio $\alpha \mathrm{CD} 28 / \alpha \mathrm{CD} 3,12.2 \mathrm{ng}$ of total antibody $/ 10^{6}$ beads; $\mathrm{Ab}$ beads: 3.6 ratio $\alpha \mathrm{CD} 28 /$ $\alpha \mathrm{CD} 3,14.5 \mathrm{ng}$ of total antibody $/ 10^{6}$ beads). No soluble IL-2 was added to the culture, to establish the pure effect of the PIC beads on $\mathrm{T}$ cell activation. We observed that the IFN $\gamma$ production of $\mathrm{T}$ cells stimulated with PIC beads was remarkedly upregulated (3.1-fold) after 1 day of stimulation compared to $\mathrm{Ab}$ beads (Figure $1 \mathrm{~b}$ ). Even more pronounced, IL-2 production of $\mathrm{T}$ cells stimulated with the PIC beads was increased 17 -fold compared to exposure to $\mathrm{Ab}$ beads (Figure 1c). Three days of $\mathrm{T}$ cell stimulation with PIC beads led to a high proliferative character, similar to that of $\mathrm{T}$ cells cultured together with $\mathrm{Ab}$ beads (Figure $1 \mathrm{~d}$ ).

Next, to investigate the impact of immobilization of PIC on their performance, we compared the $\mathrm{T}$ cell activation potential of $\alpha \mathrm{CD} 3 / \alpha \mathrm{CD} 28$ PIC immunobrush beads with soluble $\alpha \mathrm{CD} 3 / \alpha \mathrm{CD} 28$ PICs. ${ }^{37,38,40}$ Human $\mathrm{T}$ cells were stimulated with similar amounts of $\alpha \mathrm{CD} 3$ and $\alpha \mathrm{CD} 28$ immobilized on PIC beads ( 1 bead per cell) or soluble PIC $^{43}$ having similar 

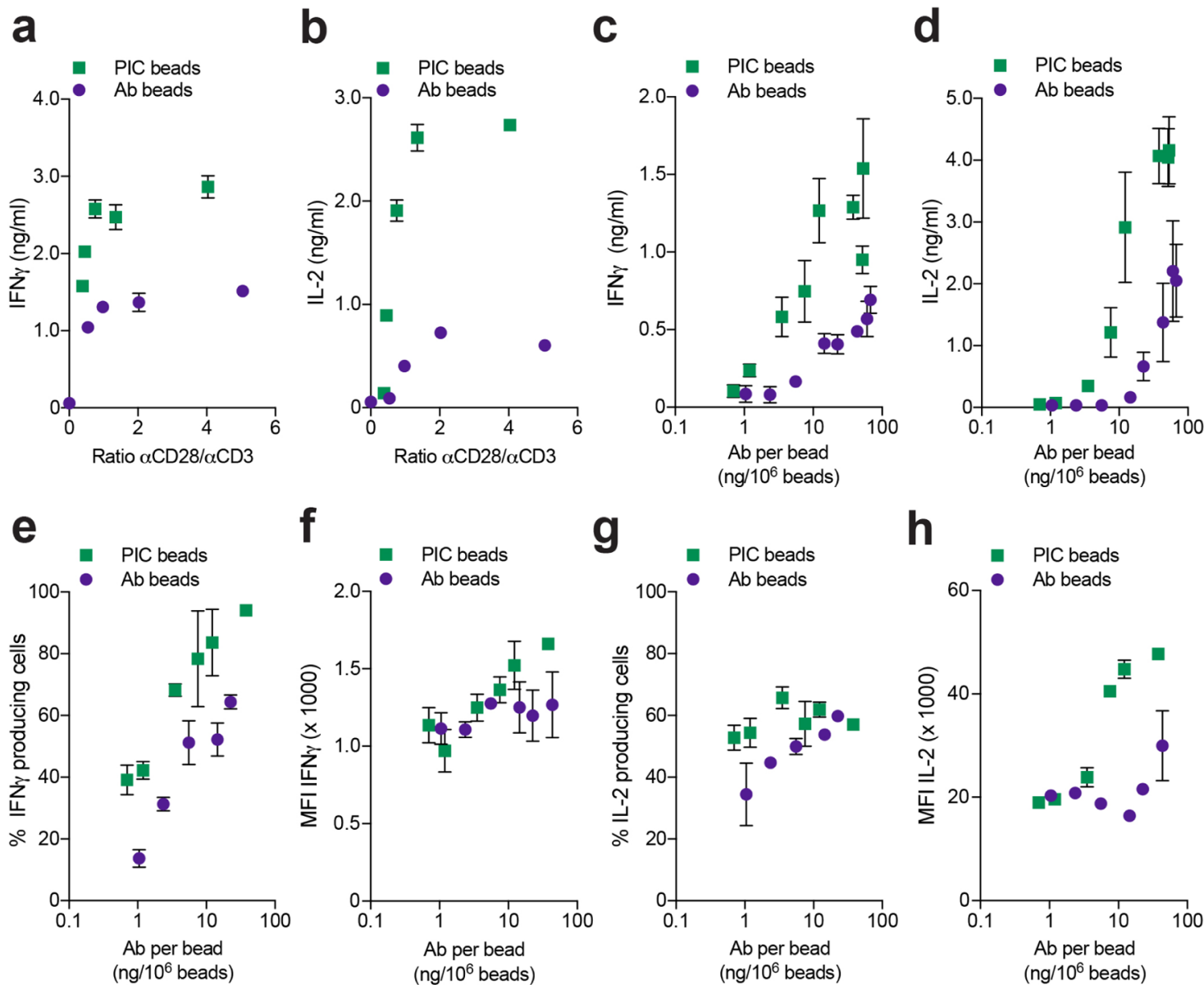

Figure 2. Influence of $\alpha \mathrm{CD} 28 / \alpha \mathrm{CD} 3$ ratio and density. (a, b) IFN $\gamma$ and IL-2 concentrations in the supernatant of T cells stimulated with Ab or PIC beads with different $\alpha \mathrm{CD} 28 / \alpha \mathrm{CD} 3$ ratios after $24 \mathrm{~h}$ of culture $n=3$ in two independent experiments. (c, d) IFN $\gamma$ and IL-2 concentrations in the supernatant of $\mathrm{T}$ cells stimulated with $\mathrm{Ab}$ or PIC beads with different total antibody densities after $24 \mathrm{~h}$ of culture $n=4$ and 3 , respectively, in two independent experiments. (e) Percentage of IFN $\gamma$ producing T cells after 7 days of culture with Ab or PIC beads over a full range of antibody densities. (f) Mean fluorescence intensities (MFI) of IFN $\gamma$ produced by $\mathrm{T}$ cells after 7 days of culture with Ab or PIC beads over a full range of antibody densities. (g) Percentage of IL-2 producing T cells after 7 days of culture with Ab or PIC beads over a full range of antibody densities. (h) Mean fluorescent intensities (MFI) of IL-2 produced by T cells after 7 days of culture with Ab or PIC beads over a full range of antibody densities $n$ $=2$ in one independent experiment for $(\mathrm{e})-(\mathrm{h})$.

antibody concentration and ratios (Table S1). Compared to stimulation with soluble PIC, 1 day stimulation with PIC beads led to 1.7 - and 1.9-fold increases in IFN $\gamma$ and IL-2 production, respectively (Figure S2a,b). The proliferation of PIC beadstimulated $\mathrm{T}$ cells was increased 2.5-fold (Figure S2c). Together, these results indicate that clustering the $\alpha \mathrm{CD} 3$ / $\alpha \mathrm{CD} 28$ PIC together on microbeads greatly enhances their ability to activate $\mathrm{T}$ cells.

We argued that the brush design of our PIC immunobrush beads (i.e., the polymers connected to the surface on one side at a high enough density that PIC polymers are oriented perpendicular to the bead surface) is a key factor in the observed increased activation of $\mathrm{T}$ cells. We hypothesize that, compared to antibodies directly coupled to beads, antibodies coupled to PICs have much more mobility due to the semiflexible nature of the PIC. Thus, they are better capable to follow receptor rearrangements, similar to ligands in a membrane of a natural APC, a characteristic that appeared to be very important in $\mathrm{T}$ cell activation. ${ }^{4-47}$ To substantiate this hypothesis, instead of installing biotins at one end of the PIC, we functionalized PICs with biotins randomly throughout the entire polymer (Figure 1a, bottom center). When bound to
$4.5 \mu \mathrm{m}$ streptavidin beads, the complete polymer chain is expected to be attached to the bead surface (flat PIC beads, Table S1), which reduces the ligand mobility compared to PICs attached to the surface with a single end. In addition, we aimed to rigidify the PIC brush structure by allowing the crosslinking of the single-end surface-bound $\alpha \mathrm{CD} 3 / \alpha \mathrm{CD} 28$ PICs. To this end, we grafted beads with $\alpha \mathrm{CD} 3 / \alpha \mathrm{CD} 28$ PICs for which the step to quench the excess DBCO on the antibodies was omitted. This allows reaction with the excess azides on adjacent PICs on the bead to induce cross-linking without the need for additional antibody modification (cross-linked PIC, Figure 1a, bottom right, and Table S1). Cross-linking of the PICs on the beads will reduce the PIC mobility and could have influenced accessibility of antibodies, which are present within the brush. We observed that primary human $\mathrm{T}$ cells stimulated with flat or cross-linked PIC beads did not produce substantial amounts of IFN $\gamma$ and IL-2 after 1 day of culture, whereas the PIC immunobrush beads produced large amounts of these cytokines (Figure 1e,f). Together, these results indeed indicate that the brush design and ligand mobility are important factors in the observed increase in $\mathrm{T}$ cell activation after PIC bead stimulation. 
a

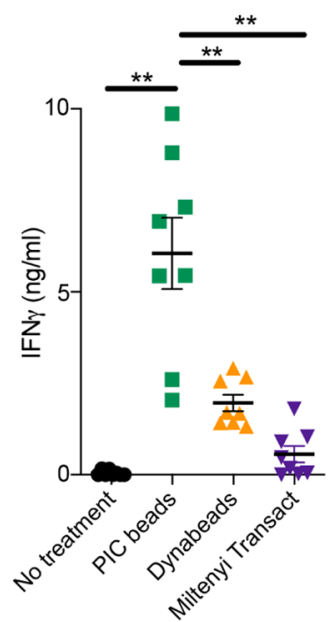

b

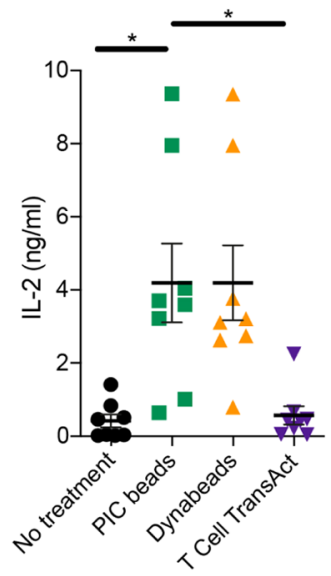

C

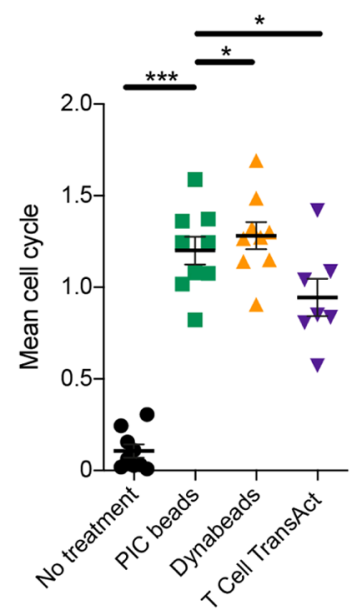

d

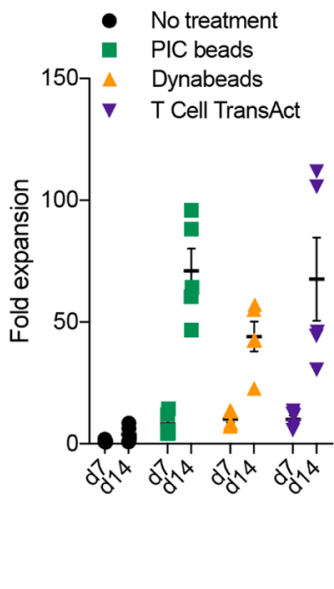

Figure 3. Polyclonal ex vivo expansion of human T cells. (a, b) IFN $\gamma$ and IL-2 concentrations in the supernatant of human T cells stimulated with different expansion systems after 1 day, respectively; $n=8$ in four independent experiments. Data were analyzed with an RM one-way ANOVA with Geisser-Greenhouse correction, followed by Dunnett's multiple comparison test. (c) Mean cell cycle of proliferated T cells on day 3, stimulated with PIC beads, Dynabeads, or T Cell TransAct; $n=6$ (T cell transact) in three independent experiments or $n=8$ (all others) in four independent experiments. Data were analyzed using a mixed-effects analysis, with the Geisser-Greenhouse correction, followed by Dunnett's multiplecomparisons test (d) fold expansion of Pan T cells after 7 and 14 days of culture. Fold expansion was calculated relative to the number of $\mathrm{T}$ cells put into the wells on day 0 (50.000); $n=4$ (T cell Transact) or $n=5$ (all others) in two independent experiments. Significance was analyzed with an RM two-way ANOVA followed by Sidak's multiple-comparisons test on log2-transformed data.

\subsection{PIC Immunobrush Beads Effectively Stimulate $T$}

Cells. Having established the importance of the brush design of our PIC beads and the benefits for T cell activation, we next optimized the ratio of the $\alpha \mathrm{CD} 3$ and $\alpha \mathrm{CD} 28$ antibodies conjugated to the PIC immunobrush. This parameter is known to affect $\mathrm{T}$ cell activation. ${ }^{17,48} \mathrm{~A}$ series of $\mathrm{Ab}$ beads and PIC immunobrush beads with $\alpha \mathrm{CD} 28 / \alpha \mathrm{CD} 3$ ratios between 0.3 and 5 were prepared (Table S1 for all formulations). Human $\mathrm{T}$ cells were stimulated with one bead per cell ratio for both $\mathrm{Ab}$ beads and PIC beads. No significant differences in the proliferation of $\mathrm{T}$ cells after 3 days of culture was observed between the different $\alpha \mathrm{CD} 28 / \alpha \mathrm{CD} 3$ ratios, independent of the platform used, with a maximum proliferation rate already reached at the lowest $\alpha \mathrm{CD} 28 / \alpha \mathrm{CD} 3$ ratio for both $\mathrm{Ab}$ beads and PIC beads (Figure S3a). By contrast, PIC beads induced much higher amounts of cytokines (IFN $\gamma$ and IL-2) over the full range of ratios, compared to the $\mathrm{Ab}$ beads (Figure 2a,b). Although a maximum cytokine secretion was reached at 0.75 (IFN $\gamma$ ) and 1.4 (IL-2) $\alpha \mathrm{CD} 28 / \alpha \mathrm{CD} 3$ ratios for both $\mathrm{Ab}$ and PIC beads, the plateau secretion levels for IFN $\gamma$ and IL-2 were 1.9- and 4.5-fold higher for PIC beads, respectively. Based on these results we selected $\alpha \mathrm{CD} 28 / \alpha \mathrm{CD} 3$ ratios higher than 2.5 for further experiments to guarantee robust and reproducible $\mathrm{T}$ cell stimulation and cytokine production.

Next, the effect of antibody density was investigated, which is another main parameter that affects $\mathrm{T}$ cell activation. ${ }^{38,49}$ To this end, we synthesized $\mathrm{Ab}$ beads and PIC immunobrush beads with a fixed $\alpha \mathrm{CD} 28 / \alpha \mathrm{CD} 3$ ratio of around 3, but varied the density of the antibodies on the beads. The density was controlled by addition of variable amounts of either biotinylated $\alpha \mathrm{CD} 28 / \alpha \mathrm{CD} 3$ to obtain $\mathrm{Ab}$ beads, or DBCOfunctionalized $\alpha \mathrm{CD} 28 / \alpha \mathrm{CD} 3$ coupled to biotinylated brush PIC to generate PIC immunobrush beads (Table S1). Stimulation of $\mathrm{T}$ cells with both types of beads reached the same level of maximum proliferation (Figure S3b). The PIC beads, however, reached this maximum at lower antibody densities ( 3.5 instead of $22 \mathrm{ng}$ antibody per million beads). For the IFN $\gamma$ and IL-2 production (Figure 2c,d), a higher maximum was observed for the PIC immunobrush beads, which was reached at lower antibody densities compared to $\mathrm{Ab}$ beads. Altogether, these data demonstrate that $\alpha \mathrm{CD} 3 / \alpha \mathrm{CD} 28$ PIC immunobrush beads outperform $\mathrm{Ab}$ beads, requiring considerably less antibodies to achieve robust $\mathrm{T}$ cell activation with higher levels of cytokine production.

To investigate the origin of the increased cytokine levels induced by PIC immunobrush beads, we performed intracellular cytokine staining on $\mathrm{T}$ cells to determine cytokine production at the single-cell level by flow cytometry. We observed that PIC beads induced a higher percentage of IFN $\gamma$ positive $\mathrm{T}$ cells in comparison to $\mathrm{Ab}$ bead stimulated $\mathrm{T}$ cells (Figure 2e). In contrast, the amount of IFN $\gamma$ as measured by the mean fluorescence intensity (MFI) produced by individual $\mathrm{T}$ cells is similar for both $\mathrm{Ab}$ and PIC beads (Figure 2f), indicating that the higher IFN $\gamma$ levels observed in the culture supernatant are a result of the induction of a larger population of IFN $\gamma$-producing cells. Interestingly, for IL- 2 , the situation is inverse. Here, no clear differences in the percentage of IL-2 producing $\mathrm{T}$ cells are found between stimulation with $\mathrm{Ab}$ or PIC beads for all tested densities (Figure 2g), but an approximately 2-fold higher IL-2 MFI was measured in $\mathrm{T}$ cells stimulated with PIC beads (Figure $2 \mathrm{~h}$ ). These findings indicate that activation of $\mathrm{T}$ cells via PIC immunobrushes affects the production of the different cytokines via different mechanisms.

\subsection{Ex Vivo Polyclonal Expansion of Primary Human} T Cells. Having determined the optimal parameters for our PIC immunobrush bead design $(\alpha \mathrm{CD} 28 / \alpha \mathrm{CD} 3$ ratios higher than 2.5 , and a minimal antibody density of around $12 \mathrm{ng} /$ million beads), we next evaluated their capability to expand $\mathrm{T}$ cells according to a clinically used protocol. CD3/CD28 Dynabeads and $\mathrm{T}$ Cell TransAct are two systems that are frequently used for ex vivo expansion of $\mathrm{T}$ cells for adoptive $\mathrm{T}$ 
a
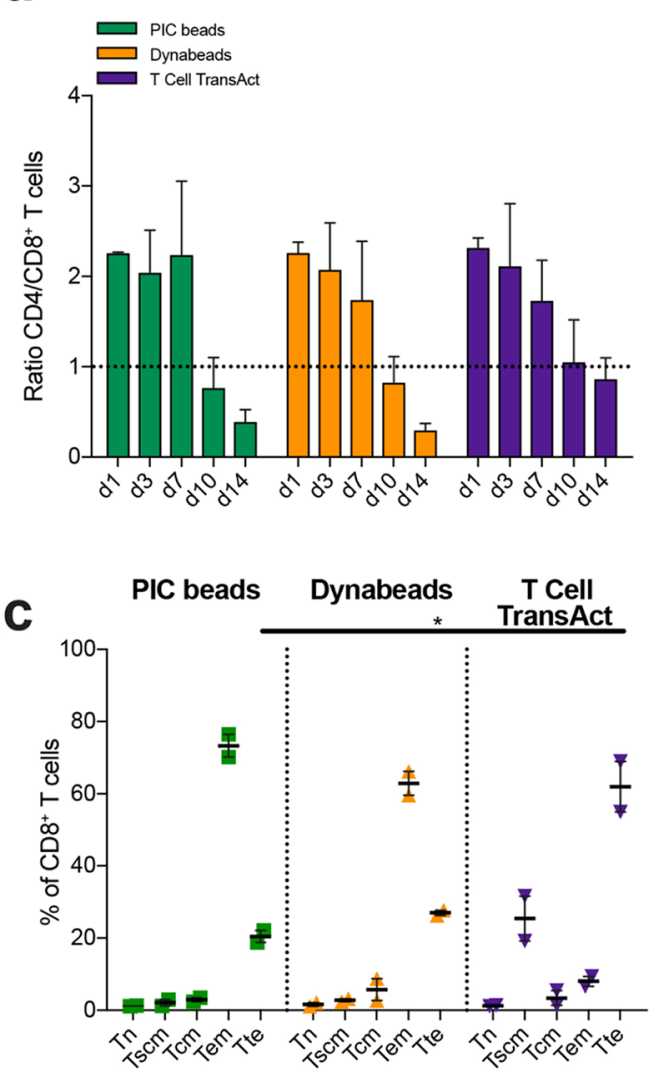

f

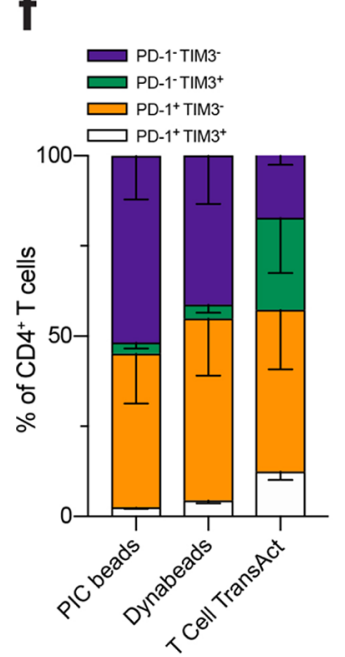

g

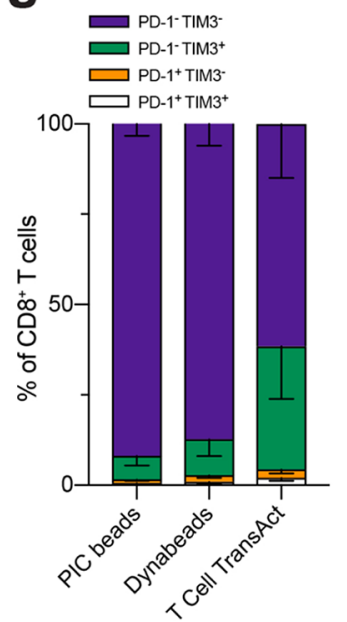

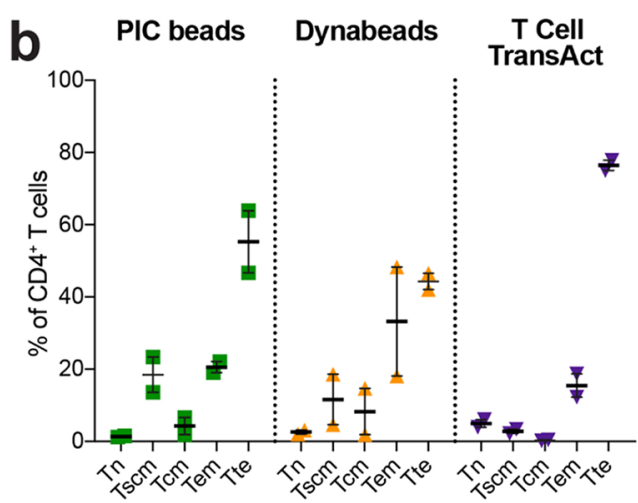

d

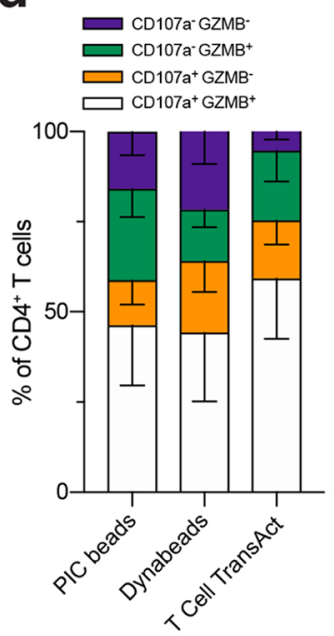

e
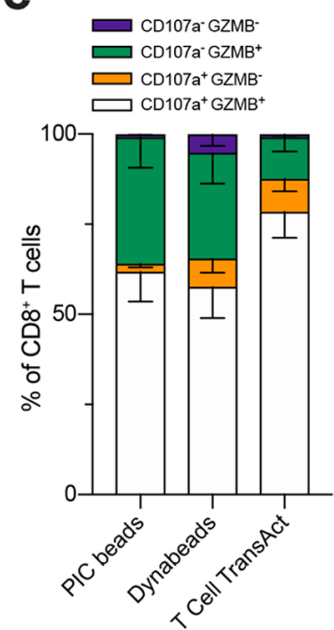

i

h

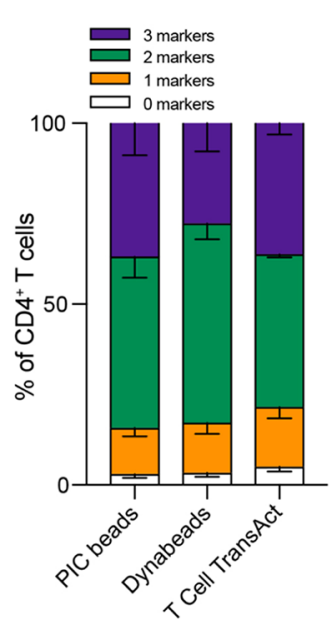

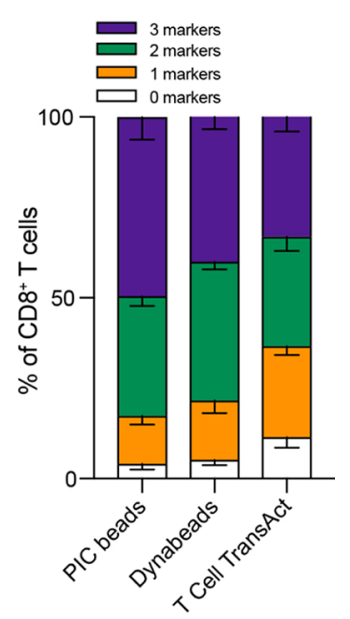

Figure 4. Phenotype and function of human T cells expanded with PIC immunobrush beads on day 14. (a) Ratio of CD4 ${ }^{+}-\mathrm{CD} 8^{+}$human $\mathrm{T}$ cells after expansion $n=2-5$ in one or two independent experiments. Data were analyzed using a mixed-effects model, followed by a Dunnett's multiplecomparisons test on log2-transformed data. $(\mathrm{b}, \mathrm{c}) \mathrm{CD} 4^{+}$and $\mathrm{CD} 8^{+}$differentiation of human $\mathrm{T}$ cells in to different memory subsets after expansion with PIC beads, Dynabeads, or T Cell TransAct, respectively; $n=2$ in one independent experiment. (d) CD4 $4^{+}$and (e) CD8 ${ }^{+}$cytotoxic character of human T cells after expansion; $n=5$ in two independent experiments. Statistics: $\mathrm{CD}^{+} \mathrm{T}$ cells: $\mathrm{CD}_{107^{-}} \mathrm{GZMB}^{+}$PIC beads $v s$ Dynabeads $p<0.05$.

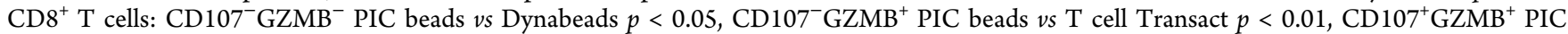
beads vs $\mathrm{T}$ cell Transact $p<0.05$. (f, g) $\mathrm{CD}^{+}$and $\mathrm{CD}^{+}$exhaustion character of human $\mathrm{T}$ cells after expansion, respectively; $n=5$ in two independent experiments. Statistics: $\mathrm{CD} 4^{+} \mathrm{T}$ cells: PD- $1^{-} \mathrm{TIM}^{-}$PIC beads $v s \mathrm{~T}$ cell Transact $p<0.01, \mathrm{PD}-1^{-} \mathrm{TIM}^{+}$PIC beads $v s \mathrm{~T}$ cell Transact $p<0.05$, PD- $1^{+}$TIM- $3^{+}$PIC $v s$ T cell Transact $p<0.01$. CD $8^{+}$T cells: PD- $1^{-} \mathrm{TIM}^{+}$PIC beads $v s$ T cell Transact $p<0.01, \mathrm{PD}^{+} 1^{+} \mathrm{TIM}^{+} \mathrm{PIC} v s \mathrm{~T}$ cell Transact $p<0.01$. (h, i) Intracellular expression of $0,1,2$, or 3 cytokines (IL-2, IFN $\gamma$ and/or TNF $\alpha$ ) in CD4 $4^{+}(\mathrm{h})$ and CD8 $8^{+}(\mathrm{i}) \mathrm{T}$ cell; $n=5$ in two independent experiments. Statistics: CD $4^{+} \mathrm{T}$ cells: three markers PIC $v s$ Dynabeads $p<0.05$. CD $8^{+} \mathrm{T}$ cells: 1 marker PIC $v s$ T cell Transact $p$ $<0.05$, 0 markers PIC $v s \mathrm{~T}$ cell Transact $p<0.05$. ( $\mathrm{b}-\mathrm{i})$ Significance was analyzed with an RM two-way ANOVA with Geisser-Greenhouse correction, followed by Dunnett's multiple-comparisons test. 
cell therapies in the clinic. The CD3/CD28 Dynabeads are 4.5 $\mu \mathrm{m}$ magnetic beads equipped with $\alpha \mathrm{CD} 3$ and $\alpha \mathrm{CD} 28$ antibodies, whereas $\mathrm{T}$ Cell TransAct is a colloidal polymeric nanomatrix conjugated to humanized $\alpha \mathrm{CD} 3$ and $\alpha \mathrm{CD} 28 .^{50}$ We compared these two systems to our PIC beads with optimized $\alpha \mathrm{CD} 28 / \alpha \mathrm{CD} 3$ ratio and density (Table S1) for their $\mathrm{T}$ cell expansion performance. For the commercial systems, manufacturer protocols were followed to ensure optimal conditions. In addition, $\mathrm{T}$ cell cultures were supplemented with IL-2 $(30 \mathrm{IU} / \mathrm{mL})$. After 1 day of culture, PIC beads and Dynabeads induced a large $(>80 \%)$ population of $\mathrm{CD} 69^{+} \mathrm{CD} 25^{+} \mathrm{T}$ cells, indicating that $\mathrm{T}$ cells are activated (Figure S4). By contrast, stimulation with $\mathrm{T}$ Cell TransAct only led to $50 \%$ of $\mathrm{CD} 69^{+} \mathrm{CD} 25^{+} \mathrm{T}$ cells (Figure S4). In line with our previous findings, PIC beads induced high amounts of IFN $\gamma$ in the supernatant after 1 day of culture, whereas T cells stimulated with CD3/CD28 Dynabeads or T Cell TransAct secreted much less cytokine (Figure 3a). PIC beads and Dynabeads, but not $\mathrm{T}$ Cell TransAct, induced high production of IL-2 by the $\mathrm{T}$ cells (Figure $3 \mathrm{~b}$ ). All systems induced robust proliferation and high viability of $\mathrm{T}$ cells compared to unstimulated cells after 3 days, although stimulation with PIC beads and Dynabeads induced the highest proliferation in terms of the proportion of $\mathrm{T}$ cells that divided and their average numbers of cycles (Figures 3c, S5, and S6). After 14 days of culture, all three systems induced robust expansion, with a 75-fold expansion of $\mathrm{T}$ cells for the PIC beads, on par with $\mathrm{T}$ Cell TransAct and greater than Dynabeads in our hands (Figure 3d). Considering that the amount of stimulating antibodies per bead is far greater on the Dynabeads versus the PIC beads $\left(\sim 450^{31}\right.$ vs $13 \mathrm{ng} /$ bead $)$, this difference is remarkable and shows the importance of the method of presentation of $\mathrm{T}$ cell activating signals.

3.4. Phenotype and Function of Ex Vivo Expanded Human T Cells. Next, we evaluated the phenotype and function of the $\mathrm{T}$ cells expanded with PIC immunobrush beads, Dynabeads, or T Cell TransAct. First, the ratio of $\mathrm{CD} 4^{+}$ and $\mathrm{CD}^{+}$cells was determined on different days during the 14 days of culture. In the first week of culture, no differences in the $\mathrm{CD} 4 / \mathrm{CD}^{+}$ratio were observed irrespective of the type of stimulation (ratio of 2), but after 10 days, the population of $\mathrm{T}$ cells treated with PIC beads or Dynabeads was skewed towards $\mathrm{CD}^{+}$cells (ratio, 0.3-0.4) (Figure 4a). Treatment with T Cell TransAct yielded similar numbers of $\mathrm{CD}^{+}$and $\mathrm{CD}^{+} \mathrm{T}$ cells (ratio 0.9) on day 14.

After 14 days of culture $T$ cells, the memory phenotype of the $\mathrm{T}$ cells was determined according to the linear $\mathrm{T}$ cell differentiation model, which assumes that $\mathrm{T}$ cells linearly progress from naive $\mathrm{T}$ cells $(\mathrm{Tn})$ into $\mathrm{T}$ stem cell memory (Tscm), T central memory $(\mathrm{Tcm}), \mathrm{T}$ effector memory $(\mathrm{Tem})$, and finally $\mathrm{T}$ terminal effector (Tte) cells (Figure S7). ${ }^{51}$ During this progression, $\mathrm{T}$ cells lose self-renewal potential but gain effector functions. $\mathrm{CD}^{+} \mathrm{T}$ cells stimulated with PIC beads induced a Tte phenotype in about $55 \%$ of the cells, but also significant Tscm and Tem populations (both 20\%) were observed. Dynabead stimulation led to a comparable differentiation of $\mathrm{CD} 4^{+} \mathrm{T}$ cells, with a bit less $(\sim 45 \%)$ Tte cells. On the other hand, $\mathrm{T}$ Cell TransAct led to the predominant formation of a Tte population of around $75 \%$ for the $\mathrm{CD}^{+} \mathrm{T}$ cells (Figure $4 \mathrm{~b}$ ). PIC bead stimulation of $\mathrm{CD}^{+} \mathrm{T}$ cells led to a population of $\sim 75 \%$ Tem and $\sim 20 \%$ Tte cells. For Dynabeads, a slightly smaller Tem population of $\sim 65 \%$ and similar amounts of Tte $\mathrm{T}$ cells $(\sim 25 \%)$ were observed compared to stimulation with PIC beads. As for the $\mathrm{CD} 4^{+} \mathrm{T}$ cells, stimulation with $\mathrm{T}$ Cell TransAct led to mostly $\mathrm{CD} 8^{+} \mathrm{T}$ cells with a Tte phenotype ( $65 \%)$ and less Tem cells $(\sim 10 \%)$ (Figure 4c). These data indicate that $\mathrm{T}$ cells stimulated with either PIC beads or Dynabeads progress into less differentiated states compared to $\mathrm{T}$ cells stimulated with $\mathrm{T}$ Cell TransAct. This behavior potentially has important consequences, as less differentiated cells tend to have a higher proliferative capacity and improved persistence after adoptive cell transfer in vivo. ${ }^{52}$

To determine the potential cytotoxic capacity of the generated $\mathrm{T}$ cells, we analyzed the upregulation of CD107a and Granzyme B, well-known markers for cytotoxic potential (Figure S8). We observed after 14 days of culture that a large proportion of both $\mathrm{CD} 4^{+} \mathrm{T}$ cells (Figure $4 \mathrm{~d}$ ) and $\mathrm{CD} 8^{+} \mathrm{T}$ cells (Figure 4e) co-expressed CD107a and granzyme B after stimulation with PIC beads, CD3/CD28 Dynabeads, or T Cell TransAct. This finding indicates that all three systems are capable of inducing $\mathrm{T}$ cells with a cytotoxic phenotype, although $\mathrm{T}$ cell TransAct induced a slightly higher cytotoxic population, in line with their more pronounced Tte phenotype.

Next, we evaluated the degree of $\mathrm{T}$ cell exhaustion, a loss of effector functions due to $\mathrm{T}$ cell overstimulation, by analyzing the upregulation of immune checkpoint proteins programmed cell death protein 1 (PD-1) and T cell immunoglobulin mucin3 (TIM3) after 14 days (Figure S9). Although PD-1 and TIM3 can be viewed as activation markers because they are upregulated rapidly on activated $\mathrm{T}$ cells following stimulation, they are considered as markers for exhausted $\mathrm{T}$ cells when they remain high on stimulated $\mathrm{T}$ cells for a prolonged period of time. Co-expression of multiple exhaustion markers can indicate dysfunctional $\mathrm{T}$ cell behavior. ${ }^{53} \mathrm{CD}^{+} \mathrm{T}$ cells cocultured with $\mathrm{T}$ Cell TransAct showed the highest proportion of $\mathrm{PD}-1^{+} \mathrm{TIM}^{+} \mathrm{T}$ cells (12.5\%), suggesting that a more exhausted phenotype is induced in $\mathrm{CD}^{+} \mathrm{T}$ cells than PIC beads or Dynabeads (Figure 4f). Similarly, for $\mathrm{CD}^{+} \mathrm{T}$ cells, $\mathrm{T}$ Cell TransAct also induced the highest proportion of cells with an exhaustion phenotype, as we observed that only $~ 60 \%$ of $\mathrm{CD}^{+} \mathrm{T}$ cells stimulated with $\mathrm{T}$ Cell TransAct were PD$1^{-} \mathrm{TIM}^{-}$, in contrast to around $90 \%$ for $\mathrm{T}$ cells stimulated with either PIC beads or Dynabeads (Figure 4g).

Finally, we examined the intracellular production of cytokines IL-2, IFN $\gamma$, and TNF $\alpha$ in restimulated T cells on day 14 as a measure of their effector function (Figure S10). Even though $\mathrm{T}$ cells stimulated with $\mathrm{T}$ Cell TransAct displayed a higher proportion of $\mathrm{PD}-1^{+} \mathrm{TIM}^{+}$cells, a significant proportion of both $\mathrm{CD}^{+}$(Figures $4 \mathrm{~h}$ and S11a) and $\mathrm{CD} 8^{+}$ (Figures $4 \mathrm{i}$ and $\mathrm{S} 11 \mathrm{~b}$ ) $\mathrm{T}$ cells co-produced all three of these cytokines following stimulation with PIC beads, Dynabeads, and $\mathrm{T}$ Cell TransAct. These data suggest that all three of these systems are capable of generating functional $\mathrm{T}$ cells with cytokine-producing capabilities.

\section{DISCUSSION}

The synthesis and characterization of PIC immunobrush beads functionalized with $\mathrm{T}$ cell stimulating antibodies $(\alpha \mathrm{CD} 3 /$ $\alpha \mathrm{CD} 28)$ are reported. This novel semiflexible polymer brush surface aAPC platform results in more efficient activation of $\mathrm{T}$ cells compared to aAPCs with a similar core but with the antibodies directly attached to the bead surface instead. We have shown that $\mathrm{T}$ cell expansion is highly dependent on the characteristics of the material that delivers the activation cues to the $\mathrm{T}$ cells and that the brush orientation of the $\mathrm{CD} 3 / \mathrm{CD} 28$ PIC attached to the bead is crucial for the increased $\mathrm{T}$ cell 
activation. Hypothetically, the brush design results in a better mimic of the natural dendritic cell-T cell interaction. In contrast to many other aAPCs used ${ }^{54-58}$ to induce $\mathrm{T}$ cell activation and proliferation, the semiflexible brush beads support movement and lateral rearrangement of receptors over the membrane of $\mathrm{T}$ cells, thereby facilitating receptor clustering. This reorganization of receptors and subsequent downstream signaling are of utmost importance to obtain optimal $\mathrm{T}$ cell activation. ${ }^{459-61}$ Additionally, the antibodies bound to the PIC immunobrush will deliver a different mechanical signal to the $\mathrm{T}$ cell compared to antibodies directly attached to the rigid core of a static bead. The semiflexible nature of the polymer might play a big role here as it is known that (local) mechanical cues can greatly influence $\mathrm{T}$ cell activation. $^{32,62}$ Very soft substrates $(\leq 0.5 \mathrm{~Pa})^{62}$ do result in lower $\mathrm{T}$ cell activation as well as very stiff substrates ( $>2$ $\mathrm{MPa}),{ }^{63}$ which indicates that there is an optimal range of stiffnesses where $\mathrm{T}$ cell activation is highest. With the semiflexible character of the polymer, we most likely are in this optimal range. This notion is supported by the finding that expansion of $\mathrm{T}$ cells stimulated with $\alpha \mathrm{CD} 3 / \alpha \mathrm{CD} 28$ functionalized "soft" beads was higher compared to treatment with more rigid Dynabeads. ${ }^{64,63}$ This result is in line with our findings where $\mathrm{T}$ cells stimulated with PIC immunobrush beads proliferated and expanded much better compared to $\mathrm{T}$ cells stimulated with rigid beads. These characteristics could also be the basis for the observation that coupling $\alpha \mathrm{CD} 3$ and $\alpha \mathrm{CD} 28$ antibodies to PIC immunobrushes led to lower antibody density thresholds to achieve full $\mathrm{T}$ cell activation compared to rigid scaffolds. In line with this, our PIC immunobrush beads required 34-fold less antibody compared to Dynabeads to obtain higher numbers of expanded $\mathrm{T}$ cells. The density and ratio of the $\alpha \mathrm{CD} 3 / \alpha \mathrm{CD} 28$ antibodies on aAPCs have been shown to be important design parameters influencing T cell activation. ${ }^{66,67}$ The semiflexible nature of the brush could result in an increased effective multivalency with a higher effective number of antibodies bound to the $\mathrm{T}$ cells. ${ }^{38}$

Furthermore, we observed a dramatic increase in cytokine secretion by $\mathrm{T}$ cells stimulated with PIC immunobrush beads. While the detected amounts of both secreted IFN $\gamma$ and IL-2 were higher, the origins of the increased concentrations are different. Compared to stimulation with $\mathrm{Ab}$ beads, the number of IFN $\gamma$ producing $\mathrm{T}$ cells is increased, while for IL-2, the number of producing $\mathrm{T}$ cells is similar, but rather the amount of cytokine produced per cell is enhanced. This contradicts previous work that describes the digital secretion of IL-2 by $\mathrm{CD}^{+} \mathrm{T}$ cells triggered by a single peptide major histocompatibility complex (pMHC) ligand. Increasing the number of pMHC did not lead to increased IL-2 secretion per cell but instead enhanced the proportion of responding $\mathrm{T}$ cells. ${ }^{68}$ This might suggest that an alternative mechanism is engaged with respect to IL-2 production following polyclonal stimulation of $\mathrm{T}$ cells with PIC beads compared to antigen-specific stimulation using soluble pMHC. As such, a more in-depth analysis, for example, by looking at the (mechanical) signaling pathways that lead to cytokine production, is needed to determine the mechanism behind this finding.

The developed PIC immunobrush beads were benchmarked against two frequently used products for ex vivo expansion of $\mathrm{T}$ cells for clinical adoptive therapies, namely, CD3/CD28 Dynabeads and $\mathrm{T}$ Cell TransAct. Compared to Dynabeads, our platform resulted in 50\% more expanded $\mathrm{T}$ cells, remarkedly with only $3 \%$ of the amount of antibody present on Dynabeads. ${ }^{31}$ This larger population of expanded $\mathrm{T}$ cells activated with our PIC immunobrush beads showed a phenotype and potential functionality-as judged by cytotoxic markers, cytokine production, and exhaustion markerssimilar to $\mathrm{T}$ cells expanded with Dynabeads, showing the potential of our system. $\mathrm{T}$ Cell TransAct induced a more differentiated, terminal effector phenotype, which is considered to be less favorable, as it is shown before that less differentiated cells persist and proliferate more after adoptive cell transfer in vivo. ${ }^{52}$

Our platform is highly modular and not limited to microbeads, PICs, or $\alpha \mathrm{CD} 3 / \alpha \mathrm{CD} 28$. Previously we successfully coupled different cytokines and biomolecules to the PICs, ${ }^{38,39}$ and a next step would be the incorporation of peptide major histocompatibility complex (MHC) complexes for the antigen-specific expansion of rare $\mathrm{T}$ cell populations. Furthermore, we have shown before that PICs can be easily coupled to different types of scaffolds such as nanoparticles or flat surfaces. ${ }^{41}$ Finally, other types of flexible and semiflexible polymers could be used as brushes to investigate the effect of polymer stiffness on $\mathrm{T}$ cell activation.

\section{CONCLUSIONS}

In summary, here, we developed $\mathrm{T}$ cell activating PIC polymer immunobrush magnetic beads as a potent addition to the aAPC arsenal. This approach synergizes the best of two worlds, being the enhanced $\mathrm{T}$ cell activating capacity of agonistic antibodies conjugated to semiflexible PIC polymers, with the reported optimal size $(4.5 \mu \mathrm{m})$ and ease of purification of the magnetic beads. We demonstrate that the brush architecture is crucial for the $\mathrm{T}$ cell activating capacity. The PIC immunobrush beads induced high ex vivo expansion of functional $\mathrm{T}$ cells with low numbers of stimulating antibodies and outperformed current benchmarks by producing higher numbers of cells exhibiting a combination of beneficial phenotypic characteristics, such as reduced expression of exhaustion markers, high cytokine production, and robust expression of cytotoxic hallmarks. The ex vivo expansion of $\mathrm{T}$ cells is an important process in many immunotherapies, including adoptive $\mathrm{T}$ cell transfer. Several types of materials functionalized with biomolecules to activate and expand $\mathrm{T}$ cells have been developed and are being evaluated in clinical trials. Therefore, our PIC immunobrush strategy could contribute in making $\mathrm{T}$ cell-based immunotherapies more effective. Furthermore, our platform is highly modular, not restricted to beads, antibodies or even PICs and consequently of interest to the broader materials science community.

\section{ASSOCIATED CONTENT}

\section{SI Supporting Information}

The Supporting Information is available free of charge at https://pubs.acs.org/doi/10.1021/acsami.0c21994.

AFM analysis of PIC length; overview of all formulations used in this study; comparison with soluble PIC; influence of $\alpha \mathrm{CD} 28 / \alpha \mathrm{CD} 3$ ratio and density on proliferation; CD69 and CD25 expression of stimulated $\mathrm{T}$ cells; viability of expanded $\mathrm{T}$ cells; and detailed overview of intracellular cytokine production (PDF) 


\section{AUTHOR INFORMATION}

\section{Corresponding Authors}

Roel Hammink - Department of Tumor Immunology, Radboud Institute for Molecular Life Sciences, Radboud University Medical Center, 6525 GA Nijmegen, Netherlands; Division of Immunotherapy, Oncode Institute, Radboud University Medical Center, 6525 GA Nijmegen, Netherlands; Email: Roel.Hammink@radboudumc.nl

Martijn Verdoes - Department of Tumor Immunology, Radboud Institute for Molecular Life Sciences, Radboud University Medical Center, 6525 GA Nijmegen, Netherlands; Institute for Chemical Immunology, 6525 GA Nijmegen, Netherlands; (1) orcid.org/0000-0001-8753-3528; Email: Martijn.Verdoes@radboudumc.nl

\section{Authors}

Jorieke Weiden - Department of Tumor Immunology, Radboud Institute for Molecular Life Sciences, Radboud University Medical Center, 6525 GA Nijmegen, Netherlands; Division of Immunotherapy, Oncode Institute, Radboud University Medical Center, 6525 GA Nijmegen, Netherlands; Institute for Chemical Immunology, 6525 GA Nijmegen, Netherlands; 이이.org/0000-0002-2485-0590

Dion Voerman - Department of Tumor Immunology, Radboud Institute for Molecular Life Sciences, Radboud University Medical Center, 6525 GA Nijmegen, Netherlands; Institute for Chemical Immunology, 6525 GA Nijmegen, Netherlands

Carlijn Popelier - Department of Tumor Immunology, Radboud Institute for Molecular Life Sciences, Radboud University Medical Center, 6525 GA Nijmegen, Netherlands

Loek J. Eggermont - Department of Tumor Immunology, Radboud Institute for Molecular Life Sciences, Radboud University Medical Center, 6525 GA Nijmegen, Netherlands; Institute for Chemical Immunology, 6525 GA Nijmegen, Netherlands

Marjolein Schluck - Department of Tumor Immunology, Radboud Institute for Molecular Life Sciences, Radboud University Medical Center, 6525 GA Nijmegen, Netherlands; Division of Immunotherapy, Oncode Institute, Radboud University Medical Center, 6525 GA Nijmegen, Netherlands; Institute for Chemical Immunology, 6525 GA Nijmegen, Netherlands

Carl G. Figdor - Department of Tumor Immunology, Radboud Institute for Molecular Life Sciences, Radboud University Medical Center, 6525 GA Nijmegen, Netherlands; Division of Immunotherapy, Oncode Institute, Radboud University Medical Center, 6525 GA Nijmegen, Netherlands; Institute for Chemical Immunology, 6525 GA Nijmegen, Netherlands

Complete contact information is available at: https://pubs.acs.org/10.1021/acsami.0c21994

\section{Author Contributions}

R.H., J.W., and D.V. contributed equally to this work. The manuscript was written through contributions of all authors. All authors have given approval to the final version of the manuscript.

\section{Funding}

This work was supported by a $\mathrm{PhD}$ grant from the NWO Gravity Program Institute for Chemical Immunology, ERC Adv. Grant PATHFINDER (269019) and the Oncode
Institute. C.F. is recipient of the NWO Spinoza award and ERC Adv. Grant ARTimmune (834618). M.V. is recipient of ERC Starting grant CHEMCHECK (679921) and a Gravity Program Institute for Chemical Immunology tenure track grant by NWO.

\section{Notes}

The authors declare no competing financial interest.

\section{REFERENCES}

(1) Dunn, G. P.; Bruce, A. T.; Ikeda, H.; Old, L. J.; Schreiber, R. D. Cancer Immunoediting: From Immunosurveillance to Tumor Escape. Nat. Immunol. 2002, 3, 991-998.

(2) Pauken, K. E.; Wherry, E. J. Overcoming T Cell Exhaustion in Infection and Cancer. Trends Immunol. 2015, 36, 265-276.

(3) Drake, C. G.; Jaffee, E.; Pardoll, D. M. Mechanisms of Immune Evasion by Tumors. Adv. Immunol. 2006, 90, 51-81.

(4) Anusha, A.; Kumar, S.; Kaushik, S.; Jyoti, A. Cancer Immunotherapy. J. Pharm. Sci. Res. 2017, 9, 662-666.

(5) Restifo, N. P.; Dudley, M. E.; Rosenberg, S. A. Adoptive Immunotherapy for Cancer: Harnessing the T Cell Response. Nat. Rev. Immunol. 2012, 12, 269-281.

(6) Dudley, M. E.; Gross, C. A.; Somerville, R. P. T.; Hong, Y.; Schaub, N. P.; Rosati, S. F.; White, D. E.; Nathan, D.; Restifo, N. P.; Steinberg, S. M.; Wunderlich, J. R.; Kammula, U. S.; Sherry, R. M.; Yang, J. C.; Phan, G. Q.; Hughes, M. S.; Laurencot, C. M.; Rosenberg, S. A. Randomized Selection Design Trial Evaluating Cd8+-Enriched Versus Unselected Tumor-Infiltrating Lymphocytes for Adoptive Cell Therapy for Patients with Melanoma. J. Clin. Oncol. 2013, 31, 21522159.

(7) Rosenberg, S. A.; Yang, J. C.; Sherry, R. M.; Kammula, U. S.; Hughes, M. S.; Phan, G. Q.; Citrin, D. E.; Restifo, N. P.; Robbins, P. F.; Wunderlich, J. R.; Morton, K. E.; Laurencot, C. M.; Steinberg, S. M.; White, D. E.; Dudley, M. E. Durable Complete Responses in Heavily Pretreated Patients with Metastatic Melanoma Using T-Cell Transfer Immunotherapy. Clin. Cancer Res. 2011, 17, 4550-4557.

(8) Svane, I. M.; Verdegaal, E. M. Achievements and Challenges of Adoptive T Cell Therapy with Tumor-Infiltrating or Blood-Derived Lymphocytes for Metastatic Melanoma: What Is Needed to Achieve Standard of Care? Cancer Immunol. Immunother. 2014, 63, 10811091

(9) June, C. H. Principles of Adoptive T Cell Cancer Therapy. J. Clin. Invest. 2007, 117, 1204-1212.

(10) June, C. H.; Riddell, S. R.; Schumacher, T. N. Adoptive Cellular Therapy: A Race to the Finish Line. Sci. Transl. Med. 2015, 7, No. 280ps7.

(11) Eggermont, L. J.; Paulis, L. E.; Tel, J.; Figdor, C. G. Towards Efficient Cancer Immunotherapy: Advances in Developing Artificial Antigen-Presenting Cells. Trends Biotechnol. 2014, 32, 456-465.

(12) Smith-Garvin, J. E.; Koretzky, G. A.; Jordan, M. S. T Cell Activation. Annu Rev Immunol. 2009, 27, 591-619.

(13) Boesteanu, A. C.; Katsikis, P. D. Memory T Cells Need Cd28 Costimulation to Remember. Semin. Immunol. 2009, 21, 69-77.

(14) Sharpe, A. H. Mechanisms of Costimulation. Immunol. Rev. 2009, 229, 5-11.

(15) Cantrell, D. Signaling in Lymphocyte Activation. Cold Spring Harb. Perspect. Biol. 2015, 7, No. a018788.

(16) Neal, L. R.; Bailey, S. R.; Wyatt, M. M.; Bowers, J. S.; Majchrzak, K.; Nelson, M. H.; Haupt, C.; Paulos, C. M.; Varela, J. C. The Basics of Artificial Antigen Presenting Cells in T Cell-Based Cancer Immunotherapies. J. Immunol. Res. Ther. 2017, 2, 68-79.

(17) Li, Y.; Kurlander, R. J. Comparison of Anti-Cd3 and AntiCd28-Coated Beads with Soluble Anti-Cd3 for Expanding Human T Cells: Differing Impact on Cd8 T Cell Phenotype and Responsiveness to Restimulation. J. Transl. Med. 2010, 8, No. 104.

(18) Mescher, M. F. Surface Contact Requirements for Activation of Cytotoxic T Lymphocytes. J. Immunol. 1992, 149, 2402-2405.

(19) Hickey, J. W.; Vicente, F. P.; Howard, G. P.; Mao, H. Q.; Schneck, J. P. Biologically Inspired Design of Nanoparticle Artificial 
Antigen-Presenting Cells for Immunomodulation. Nano Lett. 2017, $17,7045-7054$.

(20) Smith, C.; Økern, G.; Rehan, S.; Beagley, L.; Lee, S. K.; Aarvak, T.; Schjetne, K. W.; Khanna, R. Ex Vivo Expansion of Human T Cells for Adoptive Immunotherapy Using the Novel Xeno-Free Cts Immune Cell Serum Replacement. Clin. Transl. Immunol. 2015, 4, No. e31.

(21) Trickett, A.; Kwan, Y. L. T Cell Stimulation and Expansion Using Anti-Cd3/Cd28 Beads. J. Immunol. Methods 2003, 275, 251255.

(22) Shi, Y.; Wu, W.; Wan, T.; Liu, Y.; Peng, G.; Chen, Z.; Zhu, H. Impact of Polyclonal Anti-Cd3/Cd28-Coated Magnetic Bead Expansion Methods on $\mathrm{T}$ Cell Proliferation, Differentiation and Function. Int. Immunopharmacol. 2013, 15, 129-137.

(23) Junker, N.; Andersen, M. H.; Wenandy, L.; Dombernowsky, S. L.; Kiss, K.; Sørensen, C. H.; Therkildsen, M. H.; Von Buchwald, C.; Andersen, E.; Straten, P. T.; Svane, I. M. Bimodal Ex Vivo Expansion of $\mathrm{T}$ Cells from Patients with Head and Neck Squamous Cell Carcinoma: A Prerequisite for Adoptive Cell Transfer. Cytotherapy 2011, 13, 822-834.

(24) Stevanović, S.; Draper, L. M.; Langhan, M. M.; Campbell, T. E.; Kwong, M. L.; Wunderlich, J. R.; Dudley, M. E.; Yang, J. C.; Sherry, R. M.; Kammula, U. S.; Restifo, N. P.; Rosenberg, S. A.; Hinrichs, C. S. Complete Regression of Metastatic Cervical Cancer after Treatment with Human Papillomavirus-Targeted Tumor-Infiltrating T Cells. J. Clin. Oncol. 2015, 33, 1543-1550.

(25) Yong, C. S. M.; Dardalhon, V.; Devaud, C.; Taylor, N.; Darcy, P. K.; Kershaw, M. H. Car T-Cell Therapy of Solid Tumors. Immunol. Cell Biol. 2017, 95, 356-363.

(26) Redeker, A.; Arens, R. Improving Adoptive T Cell Therapy: The Particular Role of T Cell Costimulation, Cytokines, and PostTransfer Vaccination. Front. Immunol. 2016, 7, No. 345.

(27) Yee, C. Adoptive T Cell Therapy: Addressing Challenges in Cancer Immunotherapy. J. Transl. Med. 2005, 3, No. 17.

(28) Hinrichs, C. S.; Rosenberg, S. A. Exploiting the Curative Potential of Adoptive T-Cell Therapy for Cancer. Immunol. Rev. 2014, 257, 56-71.

(29) Fisher, B.; Packard, B. S.; Read, E. J.; Carrasquillo, J. A.; Carter, C. S.; Topalian, S. L.; Yang, J. C.; Yolles, P.; Larson, S. M.; Rosenberg, S. A. Tumor Localization of Adoptively Transferred Indium-111 Labeled Tumor Infiltrating Lymphocytes in Patients with Metastatic Melanoma. J. Clin. Oncol. 1989, 7, 250-261.

(30) Griffith, K. D.; Read, E. J.; Carrasquillo, J. A.; Carter, C. S.; Yang, J. C.; Fisher, B.; Aebersold, P.; Packard, B. S.; Yu, M. Y.; Rosenberg, S. A. In Vivo Distribution of Adoptively Transferred Indium-111-Labeled Tumor Infiltrating Lymphocytes and Peripheral Blood Lymphocytes in Patients with Metastatic Melanoma. J. Natl. Cancer Inst. 1989, 81, 1709-1717.

(31) Cheung, A. S.; Zhang, D. K. Y.; Koshy, S. T.; Mooney, D. J. Scaffolds That Mimic Antigen-Presenting Cells Enable Ex Vivo Expansion of Primary T Cells. Nat. Biotechnol. 2018, 36, 160-169.

(32) Jin, W.; Tamzalit, F.; Chaudhuri, P. K.; Black, C. T.; Huse, M.; Kam, L. C. T Cell Activation and Immune Synapse Organization Respond to the Microscale Mechanics of Structured Surfaces. Proc. Natl. Acad. Sci. U.S.A. 2019, 116, 19835-19840.

(33) Foster, A. E.; Rooney, C. M. Improving T Cell Therapy for Cancer. Expert Opin. Biol. Ther. 2006, 6, 215-229.

(34) Xu, Y.; Zhang, M.; Ramos, C. A.; Durett, A.; Liu, E.; Dakhova, O.; Liu, H.; Creighton, C. J.; Gee, A. P.; Heslop, H. E.; Rooney, C. M.; Savoldo, B.; Dotti, G. Closely Related T-Memory Stem Cells Correlate with in Vivo Expansion of Car.Cd19-T Cells and Are Preserved by Il-7 and Il-15. Blood 2014, 123, 3750-3759.

(35) Medvec, A. R.; Ecker, C.; Kong, H.; Winters, E. A.; Glover, J.; Varela-Rohena, A.; Riley, J. L. Improved Expansion and in Vivo Function of Patient T Cells by a Serum-Free Medium. Mol. Ther.Methods Clin. Dev. 2018, 8, 65-74.

(36) Rasmussen, A.-M.; Borelli, G.; Hoel, H. J.; Lislerud, K.; Gaudernack, G.; Kvalheim, G.; Aarvak, T. Ex Vivo Expansion
Protocol for Human Tumor Specific T Cells for Adoptive $\mathrm{T}$ Cell Therapy. J. Immunol. Methods 2010, 355, 52-60.

(37) Mandal, S.; Eksteen-Akeroyd, Z. H.; Jacobs, M. J.; Hammink, R.; Koepf, M.; Lambeck, A. J. a.; van Hest, J. C. M.; Wilson, C. J.; Blank, K.; Figdor, C. G.; Rowan, A. E. Therapeutic Nanoworms: Towards Novel Synthetic Dendritic Cells for Immunotherapy. Chem. Sci. 2013, 4, 4168-4174.

(38) Hammink, R.; Mandal, S.; Eggermont, L. J.; Nooteboom, M.; Willems, P. H. G. M.; Tel, J.; Rowan, A. E.; Figdor, C. G.; Blank, K. G. Controlling T-Cell Activation with Synthetic Dendritic Cells Using the Multivalency Effect. ACS Omega 2017, 2, 937-945.

(39) Eggermont, L. J.; Hammink, R.; Blank, K. G.; Rowan, A. E.; Tel, J.; Figdor, C. G. Cytokine-Functionalized Synthetic Dendritic Cells for $\mathrm{T}$ cell Targeted Immunotherapies. Adv. Ther. 2018, 1, No. 1800021.

(40) Mandal, S.; Hammink, R.; Tel, J.; Eksteen-Akeroyd, Z. H.; Rowan, A. E.; Blank, K.; Figdor, C. G. Polymer-Based Synthetic Dendritic Cells for Tailoring Robust and Multifunctional T Cell Responses. ACS Chem. Biol. 2015, 10, 485-492.

(41) Voerman, D.; Schluck, M.; Weiden, J.; Joosten, B.; Eggermont, L. J.; van den Eijnde, T.; Ignacio, B.; Cambi, A.; Figdor, C. G.; Kouwer, P. H. J.; Verdoes, M.; Hammink, R.; Rowan, A. E. Synthetic Semiflexible and Bioactive Brushes. Biomacromolecules 2019, 20, $2587-2597$.

(42) Dommerholt, J.; Rutjes, F. P. J. T.; van Delft, F. L. StrainPromoted 1,3-Dipolar Cycloaddition of Cycloalkynes and Organic Azides. Top. Curr. Chem. 2016, 374, No. 16.

(43) Hammink, R.; Eggermont, L. J.; Zisis, T.; Tel, J.; Figdor, C. G.; Rowan, A. E.; Blank, K. G. Affinity-Based Purification of Polyisocyanopeptide Bioconjugates. Bioconjugate Chem. 2017, 28, $2560-2568$.

(44) Yokosuka, T.; Kobayashi, W.; Sakata-Sogawa, K.; Takamatsu, M.; Hashimoto-Tane, A.; Dustin, M. L.; Tokunaga, M.; Saito, T. Spatiotemporal Regulation of $\mathrm{T}$ Cell Costimulation by $\mathrm{Tcr}-\mathrm{Cd} 28$ Microclusters and Protein Kinase C Theta Translocation. Immunity 2008, 29, 589-601.

(45) Yokosuka, T.; Saito, T. The Immunological Synapse, Tcr Microclusters, and $\mathrm{T}$ Cell Activation. Curr. Top. Microbiol. Immunol. 2010, 340, 81-107.

(46) Pageon, S. V.; Tabarin, T.; Yamamoto, Y.; Ma, Y.; Nicovich, P. R.; Bridgeman, J. S.; Cohnen, A.; Benzing, C.; Gao, Y.; Crowther, M. D.; Tungatt, K.; Dolton, G.; Sewell, A. K.; Price, D. A.; Acuto, O.; Parton, R. G.; Gooding, J. J.; Rossy, J.; Rossjohn, J.; Gaus, K. Functional Role of T-Cell Receptor Nanoclusters in Signal Initiation and Antigen Discrimination. Proc. Natl. Acad. Sci. U.S.A. 2016, 113, E5454-E5463.

(47) Dustin, M. L. The Immunological Synapse. Cancer Immunol. Res. 2014, 2, 1023-1033.

(48) Kalamasz, D.; Long, S. A.; Taniguchi, R.; Buckner, J. H.; Berenson, R. J.; Bonyhadi, M. Optimization of Human T-Cell Expansion Ex Vivo Using Magnetic Beads Conjugated with Anti-Cd3 and Anti-Cd28 Antibodies. J. Immunother. 2004, 27, 405-418.

(49) Matic, J.; Deeg, J.; Scheffold, A.; Goldstein, I.; Spatz, J. P. Fine Tuning and Efficient $\mathrm{T}$ Cell Activation with Stimulatory Acd3 Nanoarrays. Nano Lett. 2013, 13, 5090-5097.

(50) Casati, A.; Varghaei-Nahvi, A.; Feldman, S. A.; Assenmacher, M.; Rosenberg, S. A.; Dudley, M. E.; Scheffold, A. Clinical-Scale Selection and Viral Transduction of Human Nä̈e and Central Memory Cd8+ T Cells for Adoptive Cell Therapy of Cancer Patients. Cancer Immunol. Immunother. 2013, 62, 1563-1573.

(51) Mahnke, Y. D.; Brodie, T. M.; Sallusto, F.; Roederer, M.; Lugli, E. The Who's Who of T-Cell Differentiation: Human Memory T-Cell Subsets. Eur. J. Immunol. 2013, 43, 2797-2809.

(52) Busch, D. H.; Fräßle, S. P.; Sommermeyer, D.; Buchholz, V. R.; Riddell, S. R. Role of Memory T Cell Subsets for Adoptive Immunotherapy. Semin. Immunol. 2016, 28, 28-34.

(53) Wherry, E. J.; Kurachi, M. Molecular and Cellular Insights into T Cell Exhaustion. Nat. Rev. Immunol. 2015, 15, 486-499. 
(54) Steenblock, E. R.; Fadel, T.; Labowsky, M.; Pober, J. S.; Fahmy, T. M. An Artificial Antigen-Presenting Cell with Paracrine Delivery of Il-2 Impacts the Magnitude and Direction of the T Cell Response. J. Biol. Chem. 2011, 286, 34883-34892.

(55) Steenblock, E. R.; Fahmy, T. M. A Comprehensive Platform for Ex Vivo T-Cell Expansion Based on Biodegradable Polymeric Artificial Antigen-Presenting Cells. Mol. Ther. 2008, 16, 765-772.

(56) Sunshine, J. C.; Perica, K.; Schneck, J. P.; Green, J. J. Particle Shape Dependence of Cd8+ T Cell Activation by Artificial Antigen Presenting Cells. Biomaterials 2014, 35, 269-277.

(57) Meyer, R. A.; Sunshine, J. C.; Perica, K.; Kosmides, A. K.; Aje, K.; Schneck, J. P.; Green, J. J. Biodegradable Nanoellipsoidal Artificial Antigen Presenting Cells for Antigen Specific T-Cell Activation. Small 2015, 11, 1519-1525.

(58) Fadel, T. R.; Sharp, F. A.; Vudattu, N.; Ragheb, R.; Garyu, J.; Kim, D.; Hong, E.; Li, N.; Haller, G. L.; Pfefferle, L. D.; Justesen, S.; Herold, K. C.; Fahmy, T. M. A Carbon Nanotube-Polymer Composite for T-Cell Therapy. Nat. Nanotechnol. 2014, 9, 639-647.

(59) Alarcón, B.; Mestre, D.; Martínez-Martín, N. The Immunological Synapse: A Cause or Consequence of T-Cell Receptor Triggering? Immunology 2011, 133, 420-425.

(60) Hashimoto-Tane, A.; Saito, T. Dynamic Regulation of TcrMicroclusters and the Microsynapse for $\mathrm{T}$ Cell Activation. Front. Immunol. 2016, 7, No. 255.

(61) Saito, T.; Yokosuka, T. Immunological Synapse and Microclusters: The Site for Recognition and Activation of T Cells. Curr. Opin. Immunol. 2006, 18, 305-313.

(62) Saitakis, M.; Dogniaux, S.; Goudot, C.; Bufi, N.; Asnacios, S.; Maurin, M.; Randriamampita, C.; Asnacios, A.; Hivroz, C. Different Tcr-Induced T Lymphocyte Responses Are Potentiated by Stiffness with Variable Sensitivity. eLife 2017, 6, No. e23190.

(63) O'Connor, R. S.; Hao, X.; Shen, K.; Bashour, K.; Akimova, T.; Hancock, W. W.; Kam, L. C.; Milone, M. C. Substrate Rigidity Regulates Human T Cell Activation and Proliferation. J. Immunol. 2012, 189, 1330-1339.

(64) Lambert, L. H.; Goebrecht, G. K. E.; De Leo, S. E.; O’Connor, R. S.; Nunez-Cruz, S.; Li, T.-D.; Yuan, J.; Milone, M. C.; Kam, L. C. Improving T Cell Expansion with a Soft Touch. Nano Lett. 2017, 17, $821-826$.

(65) Majedi, F. S.; Hasani-Sadrabadi, M. M.; Thauland, T. J.; Li, S.; Bouchard, L.-S.; Butte, M. J. Augmentation of T-Cell Activation by Oscillatory Forces and Engineered Antigen-Presenting Cells. Nano Lett. 2019, 19, 6945-6954.

(66) Delcassian, D.; Depoil, D.; Rudnicka, D.; Liu, M.; Davis, D. M.; Dustin, M. L.; Dunlop, I. E. Nanoscale Ligand Spacing Influences Receptor Triggering in T Cells and Nk Cells. Nano Lett. 2013, 13, 5608-5614.

(67) Perica, K.; Kosmides, A. K.; Schneck, J. P. Linking Form to Function: Biophysical Aspects of Artificial Antigen Presenting Cell Design. Biochim. Biophys. Acta, Mol. Cell Res. 2015, 1853, 781-790.

(68) Huang, J.; Brameshuber, M.; Zeng, X.; Xie, J.; Li, Q.-j.; Chien, Y.-h.; Valitutti, S.; Davis, M. M. A Single Peptide-Major Histocompatibility Complex Ligand Triggers Digital Cytokine Secretion in Cd4(+) T Cells. Immunity 2013, 39, 846-857. 